\title{
Analysis by Pineapple Leaf in Chemical Pulping Process
}

\author{
Zawawi Daud", a , Mohd Zainuri Mohd Hatta ${ }^{2, b}$, Angzzas Sari Mohd Kassim,c, \\ Ashuvila Mohd Kassim ${ }^{4, d}$ and Halizah Awang ${ }^{5, \mathrm{e}}$ \\ ${ }^{1,2}$ Faculty of Civil and Environmental Engineering, Universiti Tun Hussein Onn Malaysia, 86400 \\ Parit Raja, Batu Pahat, Johor Malaysia \\ ${ }^{3,4}$ Faculty of Engineering Technology, Universiti Tun Hussein Onn Malaysia, 86400 Parit Raja, \\ Batu Pahat, Johor Malaysia \\ ${ }^{5}$ Faculty of Technical and Vocational Education, Universiti Tun Hussein Onn Malaysia, 86400 Parit \\ Raja, Batu Pahat, Johor Malaysia \\ azawawi@uthm.edu.my, ’mzainuri88@gmail.com, chalizah@uthm.edu.my,
}

Keywords: Fiber, Pineapple leaf, Green technology, Pulp and paper making.

With a proper planning and management, the agriculture waste material can give benefit to many production industries. The studied crop is pineapple (Ananas Comosus) leaf. The objective of this work was to analysis the chemical pulping and papermaking properties of pineapple leaf and; to investigate the fiber morphology of properties of those crops. At first, chemical pulping of pineapple leaf was conducted in this analysis followed the physical and mechanical properties. The result showed that in chemical pulping, reached $79.26 \%$ pulp yields had been produced and the strength properties: tear index, tensile index, burst and fold verified that they were of an acceptable quality for papermaking. This crop morphology was observed by Scanning Electron Microscopic (SEM), which showed a condensed composition of fiber structure. This study can promote the green technology in developing a friendly product and suitable to be used as an alternative pulp in paper making industry.

\section{INTRODUCTION}

Malaysia has an abundance of agro waste material that have not been fully utilized to a maximum production. Thus, the finding of a new alternative fiber in non wood material will be favorable in paper production. Pineapple (Ananas Comosus) is the common tropical plant, which consists of coalesced berries. This pineapple is leading member of the family of Bromeliaceae and it came from genus Ananas. Fiber bundle from pineapple leaf can be separated from the cortex where it reveals the pineapple leaf fiber in multi-cellular and lignocelluloses pattern. This leaf has a ribbon-like structure and cemented together by lignin, pentosan-like materials, where it contributes to the strength of fiber [7]. All parts in pineapple from fruits to leaves could be consumed to give a health benefit for human life.. Leaves of pineapple had been used as coarse textiles because of the fiber composition and structure inside the leaves [3]. All fibrous in non wood materials especially pineapple leaf consists of cellulose, holocellulose, hemicelluloses and lignin along with some extraneous material called extractives such as gum and resin. Pineapple leaf fibers also consist of lignin [23], an adhesive component that binds the cellulose and hemicellulose. Pineapple leaf fiber had the lowest lignin content than other alternative fiber, which is favorable during chemical processing [12]. The chemical composition aspects have been considered in the previous literature, such as banana stem, coconut and oil palm and had been reported extensively. Pineapple leaf reported has a lowest lignin $(10.5 \%)$ rather than banana stem $(18.6 \%)$, oil palm $(20.5 \%)$ and coconut (32.8\%) that suggest can undergo bleaching more easily and have high fiber strength [12]. Those properties depend on the content of chemical composition in the pineapple leaf fiber, which is cellulose, hemicelluloses and lignin content [15].

Therefore, the purpose of this study was to analysis the chemical compositions and to determine the chemical pulping and papermaking properties of pineapple leaf. 


\section{METHODOLOGY}

Preparation of samples. Pineapple leaf material is collected from Air Hitam, Johor. The prepared sample undergoes TAPPI Method T264 om-97 before analyses of chemical composition in pineapple leaf.

Chemical pulping. The sample will be cut into small pieces pressed until the fibbers from the nonwood material were coming out. The cooking condition for both processes can be indicated in the table below in digester autoclave. The partially delignified pulps obtained were washed with water to neutralize the reaction. Then, the pulps will be disintegrated and pressurize the moisten soda pulps for fibrillation until the freeness of the fiber of soda pulps. The formation of paper followed TAPPI Method 205 om-8.

Table 1 Sodium Hydroxide (NaOH) Pulping Process.

\begin{tabular}{|l|c|}
\hline \multicolumn{1}{|c|}{ Item } & $\begin{array}{c}\text { Soda Pulping } \\
(\mathrm{NaOH})\end{array}$ \\
\hline Concentration $(\%)$ & 15 \\
\hline Cooking time $(\mathrm{min})$ & 90 \\
\hline Cooking temperature $\left({ }^{\circ} \mathrm{C}\right)$ & 170 \\
\hline Liquor to wood ratio & 7 \\
\hline
\end{tabular}

Paper Properties. A set of paper-sheets $(60 \mathrm{~g} / \mathrm{m} 2)$ were made from the pulp of sample in one attempt according to Tappi T205 and keep overnight in a conditioning room in accordance with Tappi T402. The tensile and tear index were measured according to Tappi T494 and T414. The burst index of papers was also measured according Tappi T403. Besides that, Tappi T511 was used to measure the fold of the paper sample.

Surface Observation. The samples were observed under a Scanning Electron Microscope, SEM to study its fiber morphological properties.

\section{RESULTS AND DISCUSSION}

Pulping Process. The main performances from the highly rated pulping are the screen pulp yield and quality of fiber sheets that were produced. The chemical pulp yields are shown in table 3 . The condition of the cooking process had been set shows an optimization for this pineapple leaf fiber for chemical cooking process ( $15 \%$ sodium hydroxide, a liquor ratio $7: 1$ at $170^{\circ} \mathrm{C}$ for 90 minutes). The high pulp yield depends on the charge concentration, cooking time, cooking temperature and type of the pulping process [25]. Pineapple leaf gives almost of fully percentage pulp in this charge of the condition (above $70 \%$ of pulp yield). However, there were still having lots of pulps in this chemical cooking process. Alkali catalyzed reaction is mainly being responsible for the lost of the pulp yield during alkaline pulping of lignocellulosic [1]. The cooking process also affects the fiber length, coarseness and fines content [19]. This has slightly happened because of the condition of the cooking process and type of cooking process itself.

Papermaking Properties. The mechanical properties of pulp sheets are reported in table 3 . These properties include the measurement of tear index, tensile index, burst index, folding endurance and tear index. s seen from the Table 3, pineapple leaf fibers have a good condition to become a quality paper production. Tensile index and tear index were probably the main used for the direct measurement of the paper strength. Tensile and tearing are some of the mostly used for testing the properties of natural fiber [7]. 
Table 3 Properties of Pineapple Leaf Chemical Pulping fiber.

\begin{tabular}{|c|c|c|c|c|c|}
\hline Sample & $\begin{array}{c}\text { Pulp Yield } \\
(\%)\end{array}$ & $\begin{array}{c}\text { Tensile } \\
\text { Index } \\
\text { (Nm/g) }\end{array}$ & $\begin{array}{c}\text { Tear Index } \\
\left(\mathrm{Nm}^{2} / \mathrm{g}\right)\end{array}$ & $\begin{array}{l}\text { Burst Index } \\
\left(\mathrm{kPa}^{*} \mathrm{~m}^{2} / \mathrm{g}\right)\end{array}$ & $\begin{array}{c}\text { Folding } \\
\text { (Nm) }\end{array}$ \\
\hline $\begin{array}{l}\text { Pineapple Leaf } \\
\text { (This study) }\end{array}$ & 79.26 & 2.03 & 7.92 & 1.28 & 1.23 \\
\hline $\begin{array}{l}\text { Date Palm Rachis } \\
\text { [11] }\end{array}$ & 94.00 & 1.09 & 4.40 & 1.32 & n.a. \\
\hline $\begin{array}{l}\text { Palmyra fruit } \\
\text { [25] }\end{array}$ & 40.70 & 13.80 & 1.12 & n.a. & n.a. \\
\hline
\end{tabular}

*n.a. Not available

From this study, a pineapple leaf sheet of paper has a tensile index of $2.03 \mathrm{Nm} / \mathrm{g}$, which is between the Date Palm rachis $(1.09 \mathrm{Nm} / \mathrm{g})$ and Palmyra fruit $(13.8 \mathrm{Nm} / \mathrm{g})$. However, pineapple leaf was ahead of tear index $\left(7.92 \mathrm{Nm}^{2} / \mathrm{g}\right)$ beside Date Palm rachis $\left(4.4 \mathrm{Nm}^{2} / \mathrm{g}\right)$ and Palmyra fruit $(1.12$ $\mathrm{Nm}^{2} / \mathrm{g}$ ). High tensile strength given tear index higher because the behavior between both tear and tensile index is contrarily (Tran 2006), where it respectively showed the interfiber bonding strength is high. The strength of properties of the sheets of paper was correlated to interfiber bonding [5]. The fiber strength is directly proportional to cellulose content for fiber pulp by cooking process where it determines the strength properties of the paper that were being produced [8].

Pineapple leaf gives a good of burst index about $1.28 \mathrm{kPa}^{*} \mathrm{~m}^{2} / \mathrm{g}$ rather but Date palm rachis was a little high about $1.32 \mathrm{kPa}^{*} \mathrm{~m}^{2} / \mathrm{g}$. However, pineapple leaf paper properties still in a good range for a paper quality. The result from burst strength shows how strong the paper from pineapple leaf material. Bursting strength was done for rupture of the paper material when consistently increases the pressure as the maximum hydrostatic pressure [24]. For folding test, pineapple leaf gives $1.23 \mathrm{Nm}$ the strength of folding endurance from the test pineapple leaf papermaking. High quality test of folding endurance shows how the paper can have a maximum of fold where have an advantage to become a tissue paper with a tiny density (Shahani 1994).

Morphological Analysis. Scanning electron microscopy (SEM) analyses pineapple leaf fiber (Fig. 1) by a cross-section (a) and the fiber (b). The SEM micrographs of cross section (Fig. 1b) analysis show a fibrillation on the surface of non wood fiber, pineapple leaf. From this cross-section, the fibrillation beside the non wood material can be seen. This fibrillation can attribute to the removal of lignin and other structural effects [17]. This morphology reveals the presence of lumen where is surround the cell wall of those materials [16]. By using SEM, the strength of fiber can be seen with the arrangement and a pack of the matrix fiber. The arrangement and pack will also affect the paper production in their strength and quality (Narenda and Yiqi 2005).
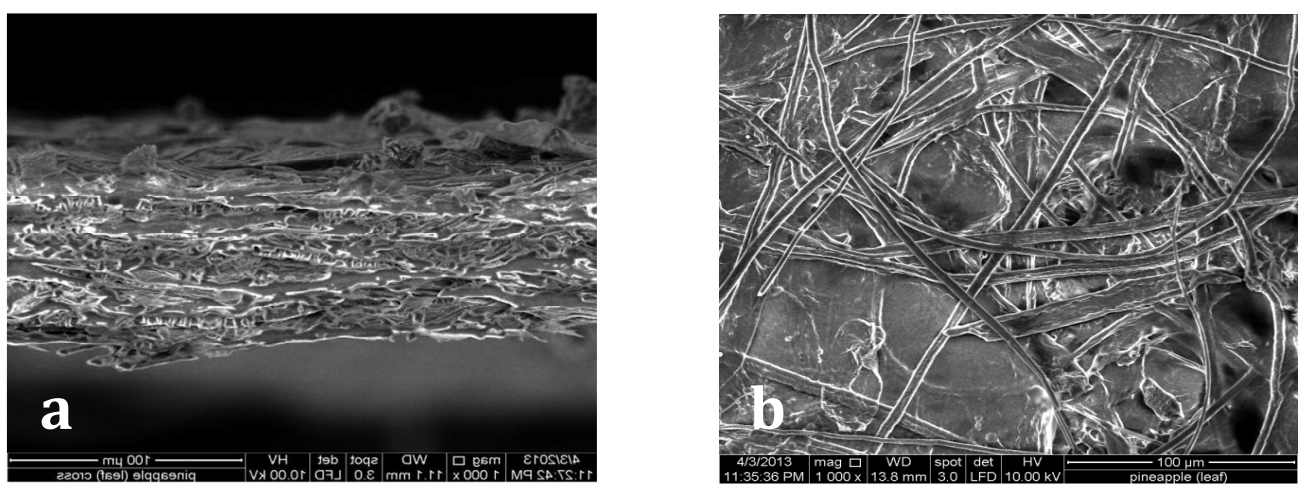

Fig. 1. Pineapple Leaf fiber (a) Cross-section (b) surface of the fiber by Scanning Electron Microscopy (SEM). 
The condensed fiber is significance to the structure of the paper produced from the non wood material [24, 18]. Matrix fiber and their arrangement of fiber make the fiber more strength where the quality of pulp and paper can be produced [25]. This could increase the fiber strength and the quality of the paper produced [9].

\section{CONCLUSIONS}

Pineapple leaf fiber becomes a favorite to become a highly potential of substitute fiber in paper production. Pineapple leafs as non wood material have a characteristic in becoming paper making production same as wood fiber. Favourable high amount of cellulose content and low lignin content could give a high quality of pulp and paper making production from pineapple leaf to become an alternative in pulp and paper making. Mechanical properties test (Tensile index, Tear index, Burst index and Fold test) shows a high of measurement where have a same property with wood material. Furthermore, scanning electron microscopy (SEM) analysis shows the condensed arrangement of fiber, which from a strong fiber structure of pineapple leaf. At last, this abundance Malaysia's agro waste material can become an effective source and has a high potential for alternative fiber in paper making industry.

\section{ACKNOWLEDGMENTS}

This research was supported by Ministry of Higher Education of Malaysia and scholarship from Universiti Tun Hussein Onn Malaysia (UTHM). The authors are thankful for this financial support.

\section{REFERENCES}

[1] R. Alen: Science and Technology Series Vol. 3(2000), p. 58-104.

[2] A. Aziz and J.Y. Zhu: New Technologies in Non-wood Fiber Pulping and Paper Making. Proceeding of $3^{\text {rd }}$ International Symposium on Emerging Technology of Pulping and Paper Making. November 8-10, Guangzhou, China. South China University of Technology. Press. 14. (2006).

[3] S. Banik, D. Nag, and S. Debnath: Fiber and Textile Vol. 36(2011), p. 172-177.

[4] M.K. Basak, S., Chanda, S.K. Bhaduri, S.B. Mondal, and R. Nandi: Industrial Crops and Products Vol. 5(1996), p. 173-176.

[5] B.K. Bhaduri, A. Day, S.B. Mondal, and S.K. Sen: Bioresource Technology Vol. 40(1992), p. 87-89.

[6] EPA: Pulp and Paper Combustion Sources National Emission Standards for Hazardous Air Pollutants: A Plain English Description. U.S. Environmental Protection Agency. EPA456/R-01-003. September 2001. (2001).

[7] J. George, S.S. Bhagawan and S. Thomas:. Journal of Thermal Analysis Vol. 47(1996), p.1121-1140.

[8] N. Gurganul, D.H. Page, and M.H. Paice: Nordic Pulp Paper Resource Vol. 3(2006), p. 152154.

[9] J.S.Han and J.S. Rowell: Paper and Composites from Agro-Based Resources Vol. 5(1999), p. 83- 134.

[10] O. Holia and T.A Jovita: Journal of Academic and Tropical Wood Technology Vol. 7((2005), p. 37-43 
[11] R. Khairi, M.F. Mhenni, , M.N. Belgacem and E. Mauret: Bioresource Technology Vol. 101(2010), p. 775-780.

[12] A.H.P.S. Khalil, S.M. Alwani and M.A.K. Omar: Bioresource Vol. 1(2006), p. 220-232.

[13] T. Khampan, N. Thavarungkul, J. Tiansuwan and S. Kamthai: International Journal of Evironmental and Earth Science Vol. 1(2010), p. 16-19.

[14] F. Lopez, A. Alfaro, M.M. Garcia, M.J. Diaz, A.M. Calero and J. Ariza: Chemical Engineering Research and Design Vol. 82(2004), p. 1029-1036.

[15] I.C. Madakadze, T. Radiotis, J.Li, K. Goel and D.L Smith: Bioresource Technology Vol. 69 (1999), p. 75-78.

[16] C. Merlini, V. Soldi and G.M.O. Barra: Polymer Testing Vol. 30(2011), p.833-840.

[17] A.K.Mohanty, M. Misra and L.T. Drzal: Natural fibers, biopolymers and biocomposites. Taylor and Francis, Boca Raton (2005).

[18] R. Narenda and Y. Yiqi: Polymer Vol. 46(2005), p. 5494-5500.

[19] H. Reza, F. Pedram, J.L. Ahmad, Y. Ni, and S.J. Sepiddehdam: Bioresource Technology Vol. 101(2010), p. 4193-4197.

[20] C. Shahani: Accelerated Aging of paper: Can it really foretell the permanence of paper. Preservation Research and Testing office. Proceeding from the ASTM/ISR Workshop on the Effects of Aging on Printing and Writing Papers in Philadelphia (1995).

[21] P. Stenius: Forest Products Chemistry Papermaking Science and Technology3 Finland: Fapet Oy ISBN 952-521-03-9. 29 (2005).

[22] A.V. Tran: Industrial Crops and Product Vol. 24(2005), p. 66-74.

[23] G. Tsoumis: Wood Material Science and Engineering Vol. 1(1991), p. 50-52.

[24] C. Ververis, K. Georghio, N. Christodoulakis, P. Santas, and R. Santas: (2004). Industrial Crops and Products Vol. 19(2004), p. 245-254.

[25] S. Waranyou: Songklanakarin Journal of Science and Technology Vol. 32(2010), p. 201205. 